\title{
Regional Integration and Cross-Border Mergers and Acquisitions in Africa
}

\author{
Magdalene Kasyoka Wilson* \\ University of Johannesburg, Johannesburg, South Africa \\ Alain Pholo Bala \\ University of Johannesburg, Johannesburg, South Africa
}

\begin{abstract}
This study uses a structural gravity model to examine how regional integration affected cross-border mergers and acquisitions (M\&As) in Africa during the period from 2000 to 2014 . We found that customs unions in Africa, specifically the Southern Africa Customs Union (SACU) and the East African Community (EAC) were significant drivers of M\&As by firms within the unions but not for those outside the unions, perhaps the result of the relatively small size of these economic blocs. The Common Market for Eastern and Southern Africa (COMESA) and Southern African Development Community (SADC) do not appear to encourage either intra- or extra- regional M\&A flows. These findings suggest that the depth of regional integration determines intra-regional M\&A flows in Africa. Therefore, African governments should strengthen existing economic integration agreements to benefit more from cross-border M\&A flows from within the regional blocs and to attract foreign investment from non-member countries.
\end{abstract}

JEL Classifications: F21, F23, C33, G34

Keywords: Mergers and acquisitions, Africa, Economic integration, Institutions, Gravity model, Foreign direct investment

\footnotetext{
* Corresponding Author: Magdalene Kasyoka Wilson; Lecturer, School of Economics, University of Johannesburg, P.O. Box 524, Auckland Park 2006, Johannesburg, South Africa. E-mail: mwilson@uj.ac.za; Phone:+27 115594375 Fax: +27 115593039.

Co-Author: Alain Pholo Bala; Senior Lecturer, School of Economics, University of Johannesburg, P.O. Box 524, Auckland Park 2006, Johannesburg, South Africa. E-mail: apholo@uj.ac.za; Phone:+27 115593911 Fax: +27 115593039. 


\section{Introduction}

Since 1990, cross-border mergers and acquisitions (M\&As) have become the dominant strategy for global businesses to achieve growth, increase profits and diversify their enterprises. According to Erel et al. (2012) growth in the number of M\&A transactions worldwide increased from $23 \%$ in 1998 to $45 \%$ in 2007. Furthermore, M\&A flows have been identified as the driving force behind the expansion of Foreign Direct Investment (FDI), especially in developed countries where M\&As constitute a substantial proportion of FDI, at times reaching $80 \%$ (UNCTAD 2006). This substantial growth in M\&A flows and its significance as a component of FDI indicates the importance of understanding the factors that influence specific entry modes of FDI such as M\&As. Moreover, the existing literature on the determinants of FDI has focused on aggregate but not specific entry modes of FDI.

The literature on the determinants of the choice of entry mode in international business expansion seems to suggest differences between M\&As and greenfield investment, i.e., an investment whereby a parent company creates a new subsidiary in a foreign country. Nocke and Yeaple (2007) examine how firm capabilities determine the choice of entry mode in a foreign market. The authors argue that the key motive for firms entering foreign markets using M\&A entry mode is to acquire complementary, non-mobile capabilities such as distribution networks. Whereas M\&A entry mode allows the acquiring firm to obtain country specific, non-mobile capabilities from the targeted firm, for example, distribution networks, knowledge of the domestic market, greenfield investment does not because the created subsidiary is new in the foreign market. Most literature on M\&As is concentrated on domestic activities in the host countries, which are typically in developed markets. However, Erel et al. (2012, p.1045) point out that "national borders add an extra element to the calculus of domestic mergers because they are associated with additional set of frictions that can impede or facilitate mergers." In addition, Ahern et al. (2015) argue that the additional costs that are associated with cross-border mergers, including cultural differences, have strong negative effects on merger activity.

There is growing interest in the role of country characteristics in determining the location of FDI. Dunning (2009, p.60) argues that since the 1990s "the importance of location per se as a variable affecting global competitiveness of firms" became significant. Therefore, it is important to examine how country characteristics, such as the level of economic integration, institutional quality, and macroeconomic factors, influence the location decisions of foreign investors.

This research differs from the existing empirical work on M\&A flows in Africa, including Agbloyor et al. (2012), Wilson and Vencatachellum (2016) and Tunyi and Ntim (2016). First, this paper focuses on M\&A activity in Africa involving firms within the continent and those from outside the continent. Unlike many previous studies, we use a structural gravity model to investigate M\&A deals from 2000 to 2014. This period is important because it was characterized by a global commodity boom that affected resource-rich economies of the developing world, such as those in Africa. Second, literature on M\&As tends to omit information such as deal values, majority of which happen to be private mergers and small 
deals. This may lead to sample selection biases (Netter et al. 2011). In fact, it is likely that M\&As in most developing regions, and especially in Africa, are under-studied because of these sample selection biases. Using the Zephyr database, which provides more information on deal values than other M\&A deals databases, we examine both the number and the value of M\&A deals during the selected period.

Lastly, since most studies on M\&As (Ahern et al. 2015, Erel et al. 2012, Hyun and Kim 2010, Di Giovanni 2005, Rossi and Volpin 2004 and Neto et al. 2010) have focused on developed countries whose institutions and level of economic development are different from those in developing countries, we examine how locational factors affect M\&A activity in Africa. We extract a dataset of global bilateral M\&A flows from the Zephyr database. This bilateral data provides both home and host country of M\&A flows, a key ingredient in a gravity framework. A gravity model is the ideal way to study the effects of economic integration on international trade and/or FDI. Results from the regression model suggest that customs unions in Africa, specifically the East African Community (EAC) and Southern Africa Customs Union (SACU) are significant drivers of M\&As by firms from within those unions but not those from outside the unions, perhaps due to the relatively small size of the economic blocs. The Common Market for Eastern and Southern Africa (COMESA) and Southern African Development Community (SADC) do not seem to encourage either intraor extra- regional M\&A flows.

This paper is organized as follows: Section 2 reviews the literature on M\&As, highlighting the important role of regional integration in fostering FDI and M\&A flows. Section 3 presents a structural gravity model, developed from microeconomic foundations. Section 4 describes the data and explains the treatment of zero observations. Section 5 discusses the empirical results. Section 6 concludes the paper.

\section{Literature Review}

The relationship between economic integration and FDI has been of interest to researchers since the establishment of the European Economic Community (EEC). A key element of regional integration is that it expands the overall market and therefore generates interest from potential investors who want to exploit economies of scale. Sachs et al. (2004) argue that regional integration increases interest from foreign investors by increasing a market's scope. Brenton et al. (1999) assert that economic integration provides an important stimulus for both trade and FDI. Warin et al. (2009) in their empirical work covering the period from 1994 to 2005 illustrate that the integration process involved in creating the Economic and Monetary Union (EMU) doubled FDI flows within the EMU. This result complements the impact of economic integration on trade as measured by Frankel and Rose (1998).

Empirical research on the impact of regional trade agreements (RTAs) on FDI include Levy-Yeyati et al. (2003), who investigate how investment patterns between the North and the South are affected by the presence of RTAs. The authors find that regional integration agreements have a strong positive effect on FDI in developing countries. Te Velde and 
Bezemer (2006) focus on the impact of RTAs on the level of FDI inflows to developing countries, from two developed countries. The authors use a quantitative measure of the strength of integration within RTAs. Te Velde and Bezemer (2006) find that even though membership in a regional grouping can boost extra-regional FDI, the strength of trade and investment provisions within those RTAs matter.

Thus far, there is only one theoretical model that explains the relationship between regional integration and M\&As as a subset of FDI. This model, proposed by Neary (2009), suggests that a decrease in trade costs within an economic bloc encourages competition and can trigger cross-border merger waves. The argument that falling trade costs stimulate FDI is in line with the trade liberalization channel suggested by Blomstrom and Kokko (1997). Furthermore, Neary's (2009) theoretical model extends to capital market liberalization, such as the special case of a monetary union. The author argues that financial integration reduces transaction costs such as exchange rate risk, and therefore facilitates movement of capital across borders.

Neary's (2009) theory is tested by Coeurdacier et al. (2009), who investigate whether trade liberalization within the EMU and financial integration within the European Union (EU) promoted M\&As within the region and with the rest of the world. Using sector-based data for the manufacturing and service sectors of major economies, Coeurdacier et al. (2009) find that financial integration within the EU had a strong impact on horizontal M\&As in the manufacturing sector, while trade liberalization within the EMU did not benefit the service sector.

Brakman et al. (2007) test the implications of Neary's (2007) proposition that M\&As are driven by comparative advantage. Using sectoral data for the period from 1980 to 2005 from five Organization of Economic Co-operation and Development countries, Brakman et al. (2007) find that both acquiring and target firms operate in strong sectors, not weak sectors. These findings support Neary's (2007) hypothesis that low cost firms, which have comparative advantage, have an incentive to merge with or takeover high cost, weak sectors.

In summary, the existing literature provides evidence that economic integration promotes FDI and M\&A flows. However, most of the studies relate to aggregate FDI stock and not to flows or M\&As. The choice of entry mode for FDI matters; therefore, we need to specifically consider the case of M\&As as the mode of entry in Africa.

\section{Theoretical Model}

We introduce a theoretical model, developed by Head and Ries (2008) from the "inspection game" presented in Fudenberg and Tirole (1991). The model implies a trade-off between the gain of transferring control of a subsidiary to a better owner and the costs entailed by the fact that an owner is located remotely from the target country. Lacking adequate controls, the manager of the subsidiary will not have a strong incentive to optimize the worth of the affliate.

In this model, management at the acquiring company's headquarters (hereafter, HQ) 
decides whether or not to control the management of an overseas affiliate (hereafter, AF), while the affiliate chooses whether to shirk or to work. Profits depend on the contributions of both HQ and AF. HQ contributes $e$ in any case whereas AF only yields $f$ when choosing to work. At the same time, HQ decides whether to trust AF, or to monitor whether it has worked or not.

Table 1 shows the payoffs for HQ and AF. AF receives $w$ from HQ, unless the latter monitors it and uncovers shirking; in this case AF receives nothing. When AF works, it generates a gross output of $e+f$. However, working results in $g$ as a cost of effort for AF, while monitoring costs for HQ are equal to $h$.

Table 1. The inspection game

\begin{tabular}{|c|c|c|c|}
\hline \multicolumn{2}{|c|}{} & \multicolumn{2}{c|}{ Headquarters chooses } \\
\cline { 3 - 4 } \multicolumn{2}{|c|}{} & Trust $(1-z)$ & Monitor $(z)$ \\
\hline \multirow{2}{*}{$\begin{array}{c}\text { Affiliate management } \\
\text { chooses }\end{array}$} & Shirk $(y)$ & $w, e-w$ & $0, e-h$ \\
\cline { 2 - 4 } & Work $(1-y)$ & $w-g, e+f-w$ & $w-g, e+f-w-h$ \\
\hline
\end{tabular}

We follow Fudenberg and Tirole (1991) and Head and Ries (2008) by assuming that $f>w$ $>g>h$. Under these conditions, there is no Nash equilibrium involving pure strategies. In a Nash equilibrium with a mixed strategy, AF cheats with probability $y$ and HQ monitors with probability $z$. HQ's expected revenues are $e+f(1-y)$, while its expected costs are given by $h z+w(1-y z)$. Hence, the expected payoffs of HQ and AF are, respectively:

$$
\begin{gathered}
v_{h q}=e+f(1-y)-h z-w(1-y z) \\
v_{a f}=w(1-y z)-g(1-y)
\end{gathered}
$$

Agents select their respective probabilities by considering the others' probabilities as fixed. Consequently, the first-order conditions for $\mathrm{HQ}$ and $\mathrm{AF}$ are, respectively:

$$
\begin{gathered}
\frac{\partial v_{h q}}{\partial z}=-h+w y \\
\frac{\partial v_{a f}}{\partial y}=g-w z
\end{gathered}
$$

The equilibrium mixed strategy therefore implies the following probabilities $y=h / w$ and $z=$ $g / w$. Replacing these probabilities by their respective expressions into HQ's payoff, we have:

$$
v_{h q}=e+f(1-h / w)-w
$$


Optimizing this objective function with respect to $w$ yields the solution $w^{*}=\sqrt{f h}$.

This solution implies that there is a contract between HQ and AF implying that AF will be paid $\sqrt{f h}$ except when HQ notices that AF has cheated. We now have the expression for the optimal payoff function:

$$
v_{h q}=e+f-2 \sqrt{f h}
$$

As outlined by Head and Ries (2008) the most important result that flows from this expression is that higher verification costs lower the value of the affiliate to the HQ. This result is boosted when AF's effort is more valuable. In other words, if two HQs of equal value-added $e$ were bidding, the HQ with lower monitoring costs would provide the highest auction price.

We can now move one step forward to our econometric specification by assuming that monitoring costs, $h$, are an increasing function of a vector of measures of geographical and cultural distances, and of economic proximity", denoted $\boldsymbol{D}_{i j}$. We can express this "remoteness function" as follows:

$$
h_{i j}=\left[k\left(\boldsymbol{D}_{i j}\right) / 2\right]^{2} \text { with } k^{\prime}>0
$$

Replacing $h$ in Equation (6) with the formula of the remoteness function yields the following expression of the payoff function of an HQ in country $i$ monitoring a target in country $j$ :

$$
v_{i j}=e+f-2 \sqrt{f} k\left(\boldsymbol{D}_{i j}\right)
$$

We model the ownership outcome as a process whereby the HQ that expects the highest affiliate valuation makes the highest bid and wins the auction for control of the affiliate. We denote $\pi_{i j}$ as the probability that the HQ from country $i$ takes control of a randomly drawn affiliate or target in country $j . K_{j}$ is the asset value of the entire stock of targets in country $j$. The expected value of $M \& A$ between country $i$ and $j$ is given by the following equation:

$$
E\left(M \& A_{i j}\right)=\pi_{i j} K_{j}
$$

Owing to the presence of many large target sizes, which create lumpiness in data, the realized value of $M \& A$ will differ from the expected value of $M \& A$.

To specify $\pi_{i j}$ we assume that acquiror country $i$ has $m_{i}$ HQs, each of which has different valuations for a given target country $j$. We introduce heterogeneity in valuations through the HQ value-added term, $e$. We assume that the cumulative density of $e$ takes the Gumbel Type 1 Extreme Value form: $\exp (-\exp (-(x-\mu) / \sigma))$.

Using discrete choice theory (Anderson et al. 1992, p.39) it can be shown that $\pi_{i j}$ is given by a multinomial logit formula:

${ }^{1}$ An interesting measure of economic proximity is participation in regional integration such as RTA. 


$$
\pi_{i j}=\frac{\exp \left[\mu_{i} / \sigma+\operatorname{Inm}_{i}-(\sqrt{f} / \sigma) k\left(\boldsymbol{D}_{i j}\right)\right]}{\sum_{l} \exp \left[\mu_{l} / \sigma+\operatorname{Inm}_{l}-(\sqrt{f} / \sigma) k\left(\boldsymbol{D}_{l j}\right)\right]}
$$

By substituting Equation (9) into (8) we obtain the expected bilateral value of $M \& A$ as:

$$
E\left(M \& A_{i j}\right)=\frac{m_{i} \exp \left[\mu_{i} / \sigma-(\sqrt{f} / \sigma) k\left(\boldsymbol{D}_{i j}\right)\right]}{\sum_{l} m_{l} \exp \left[\mu_{l} / \sigma-(\sqrt{f} / \sigma) k\left(\boldsymbol{D}_{l j}\right)\right]} K_{j}
$$

Let the inspection cost function $k\left(\boldsymbol{D}_{i j}\right)=\left(\boldsymbol{D}_{i j}\right) \boldsymbol{\delta}$, where $\boldsymbol{\delta}$ is the distance costs of remote inspections and $\boldsymbol{\theta} \equiv \boldsymbol{\delta} \sqrt{f} / \sigma$ The compound parameter $\boldsymbol{\theta}$ measures friction costs due to the distance between countries. As just shown, $\theta$ is directly related to the distance costs of inspection $(\boldsymbol{\delta})$ and the value added by a manager who chooses not to shirk $(f)$.

Using this notation, we can then specify the bid competition, a measure of remoteness, for targets in country $j$ as $B_{j} \equiv \sum_{l} s_{l}^{m} \exp \left(\frac{\mu_{l}}{\sigma}-D_{i j} \theta\right)$, with $s_{i}^{m}=m_{i} / \sum_{l} m_{l}$ as the country's share of world bidders.

We therefore express Equation (10) as:

$$
E\left(M \& A_{i j}\right)=\frac{\exp \left(\mu_{i} / \sigma-\boldsymbol{D}_{i j} \boldsymbol{\theta}\right)}{B_{j}} s_{i}^{m} K_{j}
$$

A higher bid competition implies that it is easier for assets in country $i$ to be acquired by rivals from other countries, hence reducing the expected bilateral M\&A from country $i . B_{j}$ is similar to the "multilateral resistance term" developed in the international trade literature by Anderson and Van Wincoop (2003) and represents the market potential or supplier access. We can rewrite the right-hand side of Equation (11) as follows:

$$
\begin{array}{r}
E\left(M \& A_{i j}\right)=\exp \left[\mu_{i} / \sigma+\operatorname{Ins} s_{i}^{m}+\operatorname{In} K_{j}-\operatorname{In} B_{j}-\boldsymbol{D}_{i j} \boldsymbol{\theta}\right] \\
E\left(M \& A_{i j}\right)=\exp [\underbrace{\mu_{i} / \sigma+\ln s_{i}^{m}}_{\text {outwardeffect }}+\underbrace{\ln K_{j}-\ln B_{j}}_{\text {Inward effect }}-\boldsymbol{D}_{i j} \boldsymbol{\theta}]
\end{array}
$$

Defining the outward and the inward effects as:

$$
\begin{gathered}
\text { Out }_{i}=\frac{\mu_{i}}{\sigma}+\ln s_{i}^{m} \\
\operatorname{In}_{j}=\ln \left(K_{j}\right)-\ln B_{j}
\end{gathered}
$$


we have

$$
E\left(M \& A_{i j}\right)=\exp \left[O u t_{i}+\operatorname{In}_{j}-\boldsymbol{D}_{i j} \boldsymbol{\theta}\right]
$$

Moving from expected values determined by the theory to actual values of $M \& A$, we get:

$$
\begin{gathered}
M \& A_{i j}=E\left(M \& A_{i j}\right) \varepsilon_{i j} \\
M \& A_{i j}=\exp \left[O u t_{i}+I n_{j}-\boldsymbol{D}_{i j} \boldsymbol{\theta}\right] \varepsilon_{i j}
\end{gathered}
$$

Extending this expression to a panel data framework, we have:

$$
M \& A_{i j t}=\exp \left[O u t_{i t}+I n_{j t}+\alpha_{t}-\boldsymbol{D}_{i j t} \boldsymbol{\theta}\right] \varepsilon_{i j}
$$

where $\alpha_{t}$ represents time fixed effects.

Assuming that:

$$
\begin{gathered}
\text { Out }_{i t} \approx \beta_{1} \log G D P_{i t}+\alpha_{i} \\
I n_{j t} \approx \beta_{2} \log G D P_{j t}+\alpha_{j}
\end{gathered}
$$

we then have

$$
M \& A_{i j t}=\exp \left[\alpha_{i}+\alpha_{j}+\alpha_{t}+\beta_{1} \log G D P_{i t}+\beta_{2} \log G D P_{j t}-\boldsymbol{D}_{i j t} \boldsymbol{\theta}\right] \eta_{i j t}
$$

Taking logs on both sides:

$$
\log \left(M \& A_{i j t}\right)=\alpha_{i}+\alpha_{j}+\alpha_{t}+\beta_{1} \log G D P_{i t}+\beta_{2} \log G D P_{j t}-\boldsymbol{D}_{i j t} \boldsymbol{\theta}+v_{i j t}
$$

with $v_{i j t}=\log \left(\eta_{i j t}\right)$ and $\boldsymbol{D}_{i j t}=$ [RTA fixed effects, $Z_{i j t}$ ] where $Z_{i j t}$ is a set of control variables linked to transaction costs associated with M\&A. Hence, we have the final specification:

$$
\begin{aligned}
\log \left(M \& A_{i j t}\right)= & \alpha_{i}+\alpha_{j}+\alpha_{t}+\beta_{1} \log G D P_{i t}+\beta_{2} \log G D P_{j t} \\
& +\beta_{3} \text { BothinRTA }_{i j t}+\beta_{4} \text { OneRTA }_{i j t}+\varphi Z_{i j t}+v_{i j t}
\end{aligned}
$$

where $M \& A_{i j t}$ is the bilateral M\&As between target and acquiror countries at time $t$, and $\alpha_{i}$ and $\alpha_{j}$ are target and acquiror countries' individual effects that capture unobservable 
characteristics of target and acquiror those countries. $\alpha_{t}$ is the effect specific to year $t$ but common to all the pairs of countries, to capture common shocks (such as the 2008 global financial crisis). $G D P_{i t}$ and $G D P_{j t}$ are the target- and acquiror countries' GDPs at time $t . Z_{i j t}$ is a set of control variables linked to transaction costs associated with M\&As, which include distance, institutions, cultural, and financial variables. These variables are described in more detail in Section IV. A which follows. BothinRT $A_{i j t}=1$ if both acquiror and target countries are members of a regional economic bloc such as the SADC at time $t$; OneRT $A_{i j t}=1$ if the target country is a member of regional bloc but the acquiror country is not a member at time $t$, and $v_{i j t}$ is the error term.

We understand that ideally, the specification should include country-pair fixed effects. This would improve the identification of the effect of RTAs by controlling for all unobserved country pair heterogeneity and mitigate endogeneity biases (Dai et al. 2014) at least those generated by omitted variable biases. We attempted to include country-pair fixed effects in the estimations but encountered computational problems. We recognize the risk of endogeneity as serious; therefore, our results may measure correlations rather than causal effects.

\section{Description of Regressors, Data Description and Treatment of Zeros}

\section{A. Description of the regressors and a priori expectations}

Regional integration and $M \& A s$ : If the originator of the M\&A activity is a participating member of a regional economic bloc $\left(\right.$ BothinRTA $\left._{i j t}\right)$, the expectation is that a reduction or removal of trade barriers would enhance trade within the region. However, the removal of trade barriers would discourage horizontal M\&As, which had been previously incentivized by tariff jumping. As a result, trade becomes a substitute for horizontal FDI and M\&As. The removal of trade barriers also expands the regional market and stimulates intra-regional FDI and M\&As, hitherto stifled by tariff jumping. Notable beneficiaries are likely to be vertical intra-regional and efficiency-seeking M\&A activities, usually from more developed members of RTA. Consequently, the net effect of trade liberalization on intra-regional FDI and M\&As depends on the type and motive of the investment (Barrell and Velde 2002, Blomstrom and Kokko 1997).

If the source or acquiror of M\&As is from outside the region (OneRT $\left.A_{i j t}\right)$, the removal of trade barriers as a result of the creation of a RTA expands the market, making M\&A deals more profitable. This transmission channel is more likely to be exploited by market-seeking horizontal FDI and M\&As from outside the region, and, usually the deals target countries that are more developed within the region. An example of a more developed regional member who may attract investors from more developed countries is South Africa in the SADC.

Regardless of the source of investment, i.e., whether from the region or from outside, the choice of location of the M\&As is likely to be close to the largest market and where the costs 
of production are lowest (Te Velde and Bezemer 2006). This choice of location might explain why inter-regional inward FDI and M\&As in the SADC tends to be concentrated in South Africa.

The investment provisions channel takes place through liberalization of capital controls within a RTA. Reduction or elimination of restrictions on foreign investment is expected to bring direct benefits to M\&A activities. Investment provisions include explicit protection and treatment of FDI and M\&As, such as guarantees against appropriation of investment, and giving foreign investors national treatment. The same (more favorable) treatment as domestic investors. Explicit protection of investment is best described by the protection of property rights and the presence of dispute resolution mechanisms. Implementation of such provisions improves the investment climate and creates certainty in policy environment. Blomstrom and Kokko (1997) argue that strong property rights are one important aspect of RTAs among developing economies where political risk often inhibits foreign investment.

Institutions and M\&As: Apart from regional integration, we select three measures of institutional quality as control variables. The selected institutional variables are the level of corruption, the rule of law and political stability. These are important governance measures in developing countries, particularly in Africa, and have been previously considered as important determinants of M\&As (Alfaro et al. 2007, Di Giovanni 2005, Hyun and Kim 2010, Rossi and Volpin 2004). Foreign investors are attracted to countries with good institutions because weak institutions increase the cost of capital. Coeurdacier et al. (2009, p.12) argue "reliable institutions enhance transparency and sound legal and political systems offer a less uncertain environment to investors." Some studies claim that differences across institutions matter, that investors are attracted to countries with a similar institutional environment. Hyun and Kim (2010) argue that the quality of institutions in the host country matters. In this paper, we consider institutions in both source (Di Giovanni 2005) and host countries (Hyun and Kim 2010).

Exchange rate and $M \& A s$ : Various authors have included real and/or nominal exchange rates in analyzing the determinants of M\&A flows. Di Giovanni (2005), Hyun and Kim (2010), and Jongwanich et al. (2013) find that the relationship between the real exchange rate and M\&As is mostly negative and statistically insignificant. However, Coeurdacier et al. (2009) find that the introduction of a single currency within the EMU facilitated the movement of capital, resulting in a positive significant effect on M\&A flows in the manufacturing sector. Kamaly (2007) also finds a positive and significant relationship between nominal exchange rate changes and M\&As in 60 developing countries. These findings suggest there is a lack of consensus in the empirical literature regarding the relationship between exchange rates and M\&A flows.

International trade and M\&As: International trade and FDI are closely related. Neoclassical trade theory predicts that firms will establish a subsidiary in a foreign country to avoid paying tariffs. Therefore, trade and FDI are substitutes. This negative relationship 
is supported by the proximity-concentration trade-off (Brainard 1993) which explains that as transportation costs and trade barriers increase, firms are more likely to set up foreign affiliates and produce goods abroad, rather than produce domestically and export. However, Neary (2009) observes that during the 1990s both trade and FDI increased at the same time, with FDI growing much faster than trade. This increase in both trade and FDI in the 1990s contradicts the proximity-concentration trade-off and suggests a complementary relationship. Findings by Di Giovanni (2005) and Hyun and Kim (2010) support the complementary relationship between trade and cross-border M\&A flows.

Financial development and $M \& A s$ : Financial depth indicates the ease with which investors can source funds from financial markets, either in their home or in host countries. Raising funds from internal markets in source countries is much cheaper than raising funds from external markets in target countries as a result of asymmetric information (Froot and Stein 1991). In developing countries, the banking sector plays the key role of providing funds for investment. However, stock and bond markets are becoming an increasingly important source of finance for M\&As in these countries. Di Giovanni (2005), Hyun and Kim (2010), and Jongwanich et al. (2013) have established that the level of financial development is important for M\&A transactions.

\section{B. Data description and sources}

We construct a panel dataset for gross bilateral cross-border M\&A flows using the Zephyr database published by Bureau van Djik and the IBM business directory. An advantage of using this unique database compared to other data sources is that it is the most comprehensive database on M\&A activity and is relatively unexploited. Since the value of M\&A deals is not reported or confirmed in most cases, the dataset uses other sources of information to estimate the value of deals. This feature of the database enables us to have more data on the value of M\&A deals, especially for developing countries such as those in Africa. The database also covers deal information such as the announcement and completion dates of an acquisition. Where the deal completion date is not given, the database provides an assumed completion date. Since we use only completed deals in our empirical analysis, this aspect of completed deals is critical to our study. Other aspects of the data are standard; for example, the dataset provides details about the target- and the acquiror companies. More importantly, it provides the target- and the acquiror country and region, primary SIC code, major industrial sector, and other deal information such as deal value and certain balance sheet information.

Country-level data for macroeconomic variables such as GDP, stock market capitalization, value of stocks traded, and domestic credit provided by the financial sector are obtained from the World Bank Development Indicators database. Data on geographic variables, cultural variables, and trade are obtained from the Centre d'Études Prospectives et d'Informations Internationales (CEPII) database. Data for institutional factors such as corruption and rule of law is from the World Bank Governance Indicators and data for nominal exchange rates is from the Penn World Tables. 


\section{Treatment of zeros}

One problem with the specification of Equation (24) is that for many country pairs, the value of gross bilateral flows of M\&As between the countries in a given year is zero, since no deals occurred between country $i$ and country $j$ that year. It is important to retain the zero observations for M\&A deals to avoid losing information on why deals do not occur between countries. Keeping zero observations might help us to understand why some countries do not participate in M\&A activities at all. Zero bilateral flows are a problem if a gravity model is to be estimated in logarithmic form; however, the problem has been addressed by Silva and Tenreyro $(2006,2009)$.

If we were to drop all zero deal values, we might underestimate the effects of explanatory variables on M\&As. Therefore, we must keep these zero values to avoid losing valuable information and to avoid model misspecification. Silva and Tenreyro (2006) emphasize the importance of correctly treating zero observations of the dependent variable in a gravity equation and warn that heteroscedasticity can still be a problem in such an equation even after including country fixed effects.

Silva and Tenreyro (2006, 2010a) recommend the use of Poisson Pseudo Maximum Likelihood (PPML) to deal with both problems of zero observations and heteroscedasticity. By nature (in its original form) the Poisson model is a non-linear model, as it takes an exponential form. Therefore, the dependent variable is the level of M\&As, we do not have to take the log of zero. Instead, we can linearize the right-hand side of the model by taking logarithms where necessary. This process gives us a linear-log model, which enables us to retain zero observations for the dependent variable, but still use logs for explanatory variables. The estimator has been applied in gravity equations by Silva and Tenreyro (2010) to study the effects of currency unions.

\section{Empirical Results and Discussion}

We first briefly review the results for the control variables before discussing the main results. Results for the traditional gravity variables, economic size and distance, are consistent in all of the regressions; they show the correct signs and statistical significance. The results suggest the economic size of both the target and the acquiror countries is relevant and positively related to M\&A flows. We note that the coefficient for the acquiror country GDP is higher than that of the target or host country GDP, as expected, because acquirors tend to come from bigger economies, that are usually developed countries. Physical distance between the country pairs is significant and negatively related to M\&A flows. Greater distance between acquiror and target countries discourages M\&As because of high monitoring costs as discussed in the theoretical model. Distant affiliates become expensive and difficult to supervise.

Characteristics capturing cultural similarity such as common official language, common colony and former colony have a positive and significant effect on M\&A flows. This result 
concurs with the previous literature such as Erel et al. (2012), who established that culture matters for cross-border M\&As. Similar cultural features such as common official language or/and shared ethnicity reduce frictions in business transactions since participants can communicate easily and understand each other's business practices. When countries share an official language and colonial links, they also tend to have adopted a similar legal system. Among the cultural variables, it seems that having been previously colonized by the same power has a bigger effect (as the coefficient is higher) in promoting M\&As among country pairs than the other cultural variables. Sharing a common border does not seem to matter, as the variable is not significant, a finding similar to Pozzolo (2009).

Bilateral trade has a positive and significant result suggesting trade and M\&As complement each other. However, including bilateral trade flows in the regressions, with regional integration as an explanatory variable, can potentially lead to endogeneity problem. The results for nominal exchange rates show a negative but insignificant relationship. Institutions play a key role in the business environment; therefore, it was pertinent to include three measures of institutional quality relevant to Africa. The results for the level of corruption and political stability are consistent and indicate a positive relationship, which implies that political stability and low levels of corruption are important drivers of crossborder M\&As in Africa. The results confirm those of Tunyi and Ntim (2016) who find that a low level of corruption attracts FDI in the form of M\&As to Africa.

We also controlled for factors related to the level of financial development, as these factors have previously been found to be fundamental drivers, and at times mode-distinguishing determinants, of FDI flows. The results, which are not included but can be provided, suggest that market capitalization of the acquiror country as a percentage of its GDP is an important consideration for M\&A flows. The total value of stocks traded as a percentage of GDP has a positive relationship to M\&A flows but is significant only at the $10 \%$ level. These results may be influenced by limited data for many developing countries, especially those in Africa, that do not have established stock markets. Indeed, we observe that sample size significantly declines when financial market variables are included.

\section{A. The effect of regional integration on cross-border M\&A in Africa}

We analyze the effect on M\&As of six regional economic blocs in Africa that are at different levels of integration. First, we discuss the effects of two customs unions. The first is the SACU, the oldest RTA in Africa with a smaller common monetary union that excludes Botswana. The second customs union is the EAC. Second, we discuss the effect of three large groups of countries that are Free Trade Areas (FTAs). These are the SADC, the COMESA and the Economic Community of West African States (ECOWAS). Apart from Tanzania, Mozambique, Botswana and South Africa, all member countries of SADC are also members of COMESA; in other words, there is substantial membership overlap. Third, we examine the effect of economic integration in one monetary union, the West African Economic and Monetary Union (WAEMU) which has a common currency, the CFA franc.

The following discussion refers to the two RTA variables specified in Equation (24), 
BothinRT $A_{i j t}$, representing intra-regional exchanges, and OneRTA $A_{i j t}$, for inter-regional exchanges. Results are shown in Table 2. It is important to determine the effect of each specific RTA in Africa on cross-border M\&A flows, as this effect has not previously been established. The theoretical expectation is that falling trade costs within a regional economic bloc should encourage competition and foster M\&As (Neary 2009).

\section{B. The effect of customs unions on cross-border M\&A flows in Africa}

A customs union entails liberalization of trade within a regional bloc and the establishment of a common external tariff for non-member countries. The results for the value of M\&As flows are depicted in Table 2, columns 2, 3, and 4, while the number of M\&A deals is shown in columns 5, 6, and 7. The results show that coefficients for BothinSACU and BothinEAC have the expected positive signs and are statistically significant. This finding implies that within the SACU and EAC customs unions, there is an environment favoring M\&As among member countries (intra-regional). This result makes sense considering the increased levels of intra-regional investment by South Africa and Kenya within the SACU and EAC, respectively. The increase in intra-African FDI concurs with government and business leaders' efforts toward regional integration, referred to in the UNCTAD (2014) report. The report further notes that within the EAC and SADC, intra-regional FDI is a significant part of intra-African FDI, comprising half of intra-African investment in the EAC, and $90 \%$ in the SADC, mainly due to investment by the dominant members of the economic integration agreements, Kenya and South Africa. Furthermore, Njoroge and Ouma (2014) find that deepening regional integration in East Africa has facilitated cross-border bank expansion in the region.

The magnitude of the coefficient for BothinEAC is twice that of BothinSACU. This result is not surprising as Allard et al. (2016, p.20), who examine trade flows using a gravity model, find that "cross-border exchanges within EAC are five times larger than average regional trade flows within sub-Saharan Africa." Therefore, the finding of a relatively large coefficient for EAC compared to SACU in the case of M\&As appears to be defendable. Apart from the coefficient for OneinEAC for the number of M\&As, which is positive but insignificant, all the other coefficients for OneinEAC and OneinSACU are both negative and statistically insignificant. This negative sign for the coefficient of OneinRT $A_{i j t}$, where the target country is the only member of a regional economic bloc with the acquiror country a non-member, suggests that customs unions do not encourage investment from outside the region. The finding is contrary to Coeurdacier et al. (2009) for the manufacturing sector in the EU, but similar to the finding for the services sector in the EU, which did not attract extra-regional M\&A flows. 


\section{The effect of free trade areas on cross-border M\&A in Africa.}

We turn to the second type of economic integration agreement. A FTA entails complete removal of trade barriers among member countries, but each member remains responsible for its trade policy with non-member countries. Examining FTAs in Africa, we find that COMESA has investment provisions for intra-regional FDI, whereas SADC has investment provisions and initiatives for extra-regional FDI. But do these explicit investment provisions have any effect on intra- and extra-regional M\&A flows? We separate the analysis of COMESA and SADC to deal with the problem of overlapping memberships. Results for the value and the number of M\&A flows for COMESA and for SADC are shown in Tables 3 and 4 , respectively.

The results for BothinCOMESA and OneinCOMESA in Table 3 have inconsistent signs and are statistically insignificant. The results indicate negative coefficients for the value of M\&A flows and positive ones for the number of M\&A deals. All of the coefficients are statistically insignificant other than two regressions involving the number of M\&A deals, controlling for the rule of law. Therefore, even though COMESA has specifically provided for intra-regional FDI, the investment provisions do not seem to have a significant effect on M\&A flows within COMESA. 
Table 2. The effect of EAC, SACU and WAEMU on cross-border M\&A flows

(2000 2014)

\begin{tabular}{|c|c|c|c|c|c|c|}
\hline Variables & \multicolumn{3}{|c|}{ Value of M\&As } & \multicolumn{3}{|c|}{ Number of M\&As } \\
\hline BothinEAC & $\begin{array}{c}5.799 * * * \\
(1.300)\end{array}$ & $\begin{array}{c}5.804 * * * \\
(1.284)\end{array}$ & $\begin{array}{l}5.625 * * * \\
(1.320)\end{array}$ & $\begin{array}{c}2.776 * * * \\
(0.680)\end{array}$ & $\begin{array}{l}2.824 * * * \\
(0.683)\end{array}$ & $\begin{array}{c}2.738 * * * \\
(0.683)\end{array}$ \\
\hline OneinEAC & $\begin{array}{l}-0.604 \\
(0.985)\end{array}$ & $\begin{array}{r}-0.588 \\
(1.284)\end{array}$ & $\begin{array}{l}-0.739 \\
-(1.001)\end{array}$ & $\begin{array}{c}0.032 \\
(0.400)\end{array}$ & $\begin{array}{c}0.080 \\
(0.401)\end{array}$ & $\begin{array}{c}0.002 \\
(0.404)\end{array}$ \\
\hline BothinSACU & $\begin{array}{c}3.156^{* * *} \\
(0.673)\end{array}$ & $\begin{array}{c}2.945^{* * *} \\
(0.661)\end{array}$ & $2.785 * * *$ & $\begin{array}{c}0.614^{*} * * \\
(0.605)\end{array}$ & $\begin{array}{c}0.610 * * * \\
(0.604)\end{array}$ & $0.534 * * *$ \\
\hline OneinSACU & $\begin{array}{l}-0.299 \\
(0.311)\end{array}$ & $\begin{array}{l}-0.419 \\
(0.294)\end{array}$ & $\begin{array}{l}-0.582 \\
(0.293)\end{array}$ & $\begin{array}{l}-0.094 \\
(0.100)\end{array}$ & $\begin{array}{l}-0.117 \\
(0.101)\end{array}$ & $\begin{array}{l}-0.176^{*} \\
(0.102)\end{array}$ \\
\hline BothinWAEMU & $\begin{array}{l}-4.460 \\
(3.095)\end{array}$ & $\begin{array}{l}-6.933 \\
(4.271)\end{array}$ & & $4.311 * * *$ & $4.560 * * *$ & $\begin{array}{c}3.238 * * * \\
(1.562)\end{array}$ \\
\hline OneinWAEMU & $\begin{array}{l}-3.251 \\
(2.621)\end{array}$ & $\begin{array}{r}-5.674 \\
(3.928)\end{array}$ & $\begin{array}{l}1.243 \\
(1.719)\end{array}$ & $\begin{array}{l}1.445 \\
(1.651)\end{array}$ & $\begin{array}{c}1.700 \\
(1.692)\end{array}$ & $\begin{array}{c}0.377 \\
(1.532)\end{array}$ \\
\hline $\begin{array}{l}\text { Corruption } \\
\text { Acquiror }\end{array}$ & $\begin{array}{l}0.814 * * \\
(0.347)\end{array}$ & & & $0.157^{* *}$ & & \\
\hline Corruption Target & $\begin{array}{l}0.479 * * \\
(0.219)\end{array}$ & & & $\begin{array}{l}0.252 * * \\
(0.078)\end{array}$ & & \\
\hline $\begin{array}{l}\text { Rule of Law } \\
\text { Acquiror }\end{array}$ & & $\begin{array}{r}0.0 \\
0.3\end{array}$ & & & $\begin{array}{c}0.254 \\
(0.192)\end{array}$ & \\
\hline $\begin{array}{l}\text { Rule of Law } \\
\text { Target }\end{array}$ & & $\begin{array}{l}-0.388 \\
(0.419)\end{array}$ & & & $0.228^{* *}$ & \\
\hline $\begin{array}{l}\text { Political Stability } \\
\text { Acquiror }\end{array}$ & & & $\begin{array}{l}0.311 \\
(0.194)\end{array}$ & & & $\begin{array}{c}0.199 * * * \\
(0.057)\end{array}$ \\
\hline $\begin{array}{l}\text { Political Stability } \\
\text { Target }\end{array}$ & & & $\begin{array}{c}0.464 * * * \\
(0.191)\end{array}$ & & & $\begin{array}{c}0.192^{* * *} \\
(0.048)\end{array}$ \\
\hline Bilateral Trade & $\begin{array}{c}0.271^{* * *} \\
(0.054)\end{array}$ & $\begin{array}{c}0.273^{* * *} \\
(0.053)\end{array}$ & $\begin{array}{c}0.269 * * * \\
(0.053)\end{array}$ & $\begin{array}{c}0.273 * * * \\
(0.047)\end{array}$ & $\begin{array}{c}0.275^{* * *} \\
(0.048)\end{array}$ & $\begin{array}{c}0.274 * * * \\
(0.048)\end{array}$ \\
\hline Exchange Rate & $\begin{array}{l}-0.302 \\
(0.330)\end{array}$ & $\begin{array}{r}-0.325 \\
(0.340)\end{array}$ & $\begin{array}{l}-0.190 \\
0.274)\end{array}$ & $\begin{array}{c}0.061 \\
0.148)\end{array}$ & $\begin{array}{c}0.064 \\
(0.154)\end{array}$ & $\begin{array}{c}0.073 \\
(0.154)\end{array}$ \\
\hline Log Distance & $-0.432 * * *$ & $-0.431 * * *$ & $-0.433^{* * *}$ & $-0.538 * * *$ & $-0.537 * * *$ & $\begin{array}{c}-0.538 * * * \\
(0.065)\end{array}$ \\
\hline $\begin{array}{l}\text { Log GDP } \\
\text { Acquiror }\end{array}$ & $\begin{array}{c}1.965^{* * *} \\
(0.498)\end{array}$ & $\begin{array}{c}2.171^{* * *} \\
(0.463)\end{array}$ & $\begin{array}{c}2.160 * * * \\
(0.452)\end{array}$ & $\begin{array}{c}2.497 * * * \\
(0.246)\end{array}$ & $\begin{array}{c}2.533^{* * *} \\
(0.244)\end{array}$ & $\begin{array}{c}2.601 * * * \\
(0.250)\end{array}$ \\
\hline $\begin{array}{l}\text { Log GDP } \\
\text { Target }\end{array}$ & $1.732 * * *$ & $1.980^{* * *}$ & $\begin{array}{c}1.793 * * * \\
(0.593)\end{array}$ & $\begin{array}{c}0.859 * * * \\
(0.186)\end{array}$ & $0.904 * * *$ & $\begin{array}{c}0.932 * * * \\
(0.185)\end{array}$ \\
\hline $\begin{array}{l}\text { Common } \\
\text { Language }\end{array}$ & $\begin{array}{l}0.260^{*} \\
(0.149)\end{array}$ & $\begin{array}{l}0.261^{*} \\
(0.148)\end{array}$ & $\begin{array}{l}0.264 * \\
(0.148)\end{array}$ & $\begin{array}{c}0.607 * * * \\
(0.097)\end{array}$ & $\begin{array}{c}0.607 * * * \\
(0.097)\end{array}$ & $\begin{array}{c}0.608 * * * \\
(0.097)\end{array}$ \\
\hline Contiguity & $\begin{array}{l}-0.162 \\
(0.175)\end{array}$ & $\begin{array}{l}-0.175 \\
(0.175)\end{array}$ & $\begin{array}{l}-0.175 \\
(0.175)\end{array}$ & $\begin{array}{l}0.153 \\
(0.107)\end{array}$ & $\begin{array}{l}0.149 \\
(0.107)\end{array}$ & $\begin{array}{c}0.150 \\
(0.107)\end{array}$ \\
\hline Common Colony & $\begin{array}{c}0.492 * * * \\
(0.273)\end{array}$ & $0.500 * * *$ & $\begin{array}{c}0.499 * * * \\
(0.274)\end{array}$ & $\begin{array}{c}0.576^{* * *} \\
(0.236)\end{array}$ & $\begin{array}{c}0.579 * * * \\
(0.236)\end{array}$ & $\begin{array}{c}0.578^{* * *} \\
(0.236)\end{array}$ \\
\hline Former Colony & $\begin{array}{c}0.375^{* * *} \\
(0.127)\end{array}$ & $\begin{array}{c}0.384 * * * \\
(0.126)\end{array}$ & $\begin{array}{c}0.386^{* * *} \\
(0.126)\end{array}$ & $\begin{array}{c}0.528 * * * \\
(0.086)\end{array}$ & $\begin{array}{c}0.529^{* * *} \\
(0.086)\end{array}$ & $\begin{array}{c}0.530^{* * *} \\
(0.086)\end{array}$ \\
\hline
\end{tabular}


(Note) Gravity model of bilateral cross-border M\&A in Africa using PPML. Country dummies for both acquiror and target countries and year dummies are included in all regressions but are not reported. Observations clustered within country pairs. *** means significant at $1 \%$, ** means significant at $5 \%$ and * means significant at $10 \%$. Standard errors are in brackets. The number of observations for the value of M\&A is 156,927 and for the number of M\&A is 174,450 . Pseudo $R^{2}$ for the value of M\&A is 0.39 and for the number of M\&A is 0.75

Table 3. The effect of COMESA and ECOWAS on cross-border M\&A flows

(2000 2014)

\begin{tabular}{|c|c|c|c|c|c|c|}
\hline Val & \multicolumn{3}{|c|}{ Value of M\&As } & \multicolumn{3}{|c|}{ Number of M\&As } \\
\hline BothinCOMESA & $\begin{array}{l}-1.795 \\
(2.677)\end{array}$ & $\begin{array}{l}-3.252 \\
(3.674)\end{array}$ & $\begin{array}{l}-0.445 \\
(3.082)\end{array}$ & $\begin{array}{c}2.071 \\
(1.561)\end{array}$ & $\begin{array}{l}4.678 * * * \\
(2.122)\end{array}$ & $\begin{array}{c}2.306 \\
(1.587)\end{array}$ \\
\hline OneinCOMESA & $\begin{array}{c}0.055 \\
(2.977)\end{array}$ & $\begin{array}{l}-5.097 \\
(3.664)\end{array}$ & $\begin{array}{l}-2.040 \\
(3.237)\end{array}$ & $\begin{array}{l}1.163 \\
(1.431)\end{array}$ & $\begin{array}{l}3.769^{*} \\
(2.588)\end{array}$ & $\begin{array}{l}1.394 \\
(1.458)\end{array}$ \\
\hline BothinECOWAS & $\begin{array}{l}4.793 \\
(3.022)\end{array}$ & $\begin{array}{l}0.860 \\
(3.618)\end{array}$ & $\begin{array}{l}-0.445 \\
(3.051)\end{array}$ & $\begin{array}{c}6.575 * * * \\
(2.108)\end{array}$ & $\begin{array}{l}4.43 \\
1 .\end{array}$ & $\begin{array}{l}6.852 * * * \\
(2.179)\end{array}$ \\
\hline OneinECOWAS & $\begin{array}{l}-0.875 \\
(2.845)\end{array}$ & $\begin{array}{l}-4.800 \\
(3.499)\end{array}$ & $\begin{array}{l}-2.040 \\
(3.237)\end{array}$ & $\begin{array}{l}3.861^{*} \\
(2.060)\end{array}$ & $\begin{array}{l}1.7 \\
(1 .\end{array}$ & $\begin{array}{l}4.138^{*} \\
(2.129)\end{array}$ \\
\hline Corruption Acquiro & $\begin{array}{c}0.823^{* * *} \\
(0.348)\end{array}$ & & & $\begin{array}{l}0.154 \\
(0.100)\end{array}$ & & \\
\hline $\begin{array}{l}\text { Corruption } \\
\text { Target }\end{array}$ & $0.487 * * *$ & & & $0.248^{* * *}$ & & \\
\hline Rule of La & & $\begin{array}{c}0.082 \\
(0.349)\end{array}$ & & & $\begin{array}{r}0.2 \\
(0.1\end{array}$ & \\
\hline Rule of Law Targ & & $\begin{array}{l}-0.387 \\
(0.419)\end{array}$ & & & $\begin{array}{l}0.23 \\
(0.1\end{array}$ & \\
\hline $\begin{array}{l}\text { Political Stability } \\
\text { Acquiror }\end{array}$ & & & $\begin{array}{l}0.35 \\
-0.1\end{array}$ & & & $0.359 * *$ \\
\hline $\begin{array}{l}\text { Political Stability } \\
\text { Target }\end{array}$ & & & $\begin{array}{c}0.455^{* * *} \\
(0.154)\end{array}$ & & & $0.339^{* *}$ \\
\hline Bilateral Trade & $\begin{array}{c}0.257 * * * \\
(0.051)\end{array}$ & $\begin{array}{c}0.261 * * * \\
(0.051)\end{array}$ & $\begin{array}{c}0.269 * * * \\
(0.052)\end{array}$ & $\begin{array}{r}0.28 \\
(0.6\end{array}$ & $\begin{array}{l}0.28 \\
0\end{array}$ & $0.282 * * *$ \\
\hline Exchange Rate & $\begin{array}{l}-0.188 \\
(0.275)\end{array}$ & $\begin{array}{l}-0.323 \\
(0.341)\end{array}$ & $\begin{array}{l}-0.299 \\
(0.331)\end{array}$ & $\begin{array}{c}0.064 \\
(0.149)\end{array}$ & $\begin{array}{c}0.067 \\
(0.154)\end{array}$ & $\begin{array}{c}0.077 \\
(0.154)\end{array}$ \\
\hline Log Distance & $\begin{array}{c}-0.404 * * * \\
(0.083)\end{array}$ & $\begin{array}{c}-0.402 * * * \\
(0.084)\end{array}$ & $\begin{array}{c}0.403 * * * \\
(0.084)\end{array}$ & $-0.566^{* * *}$ & $\begin{array}{l}0.56 \\
0.0\end{array}$ & $\begin{array}{r}-0.566^{* * *} \\
(0.067)\end{array}$ \\
\hline $\log G D P A$ & $\begin{array}{l}1.970^{*} * * \\
(0.500)\end{array}$ & $2.165 * * *$ & $2.160^{* * *}$ & $2.495 * * *$ & $\begin{array}{r}2.53 \\
(0.2\end{array}$ & $2.600^{*} * *$ \\
\hline Log GDP Target & $\begin{array}{l}1.742 * * * \\
(0.644)\end{array}$ & $\begin{array}{l}1.985 * * * \\
(0.664)\end{array}$ & $1.799 * * *$ & $0.849 * * *$ & $\begin{array}{l}0.893 * * * \\
(0.175)\end{array}$ & $0.921 * * *$ \\
\hline Common Lo & $\begin{array}{l}0.216 \\
(0.139)\end{array}$ & $0.214 *$ & $\begin{array}{l}0.216^{*} \\
(0.139)\end{array}$ & $0.649 * * *$ & $\begin{array}{c}0.647 * * * \\
(0.095)\end{array}$ & $0.649 * * *$ \\
\hline Common Colony & $\begin{array}{l}0.481 * \\
(0.271)\end{array}$ & $\begin{array}{l}0.490^{*} \\
(0.271)\end{array}$ & $\begin{array}{r}0.490^{*} \\
(0.271)\end{array}$ & $0.555 * * *$ & $\begin{array}{l}0.558^{* *} \\
(0.240)\end{array}$ & $0.557 * *$ \\
\hline Former Colc & $\begin{array}{c}0.374 * * * \\
(0.128)\end{array}$ & $\begin{array}{c}0.383 * * * \\
(0.126)\end{array}$ & $\begin{array}{c}0.385^{*} * * \\
(0.126)\end{array}$ & $\begin{array}{c}0.536^{* * *} \\
(0.086)\end{array}$ & $\begin{array}{c}0.537 * * * \\
(0.085)\end{array}$ & $\begin{array}{c}0.538^{* * *} \\
(0.085)\end{array}$ \\
\hline
\end{tabular}


(Note) Gravity model of bilateral cross-border M\&A in Africa using PPML. Country dummies for both acquiror and target countries and year dummies are included in all regressions but are not reported. Observations clustered within country pairs. *** means significant at $1 \%$, ** means significant at $5 \%$ and $*$ means significant at $10 \%$. Standard errors are in brackets. The number of observations for the value of M\&A is 156,927 and for the number of M\&A is 174,450 . Pseudo $R^{2}$ for the value of M\&A is 0.39 and for the number of M\&A is 0.75

\section{Table 4. The effect of SADC on cross-border M\&A flows}

(2000 2014)

\begin{tabular}{|c|c|c|c|c|c|c|}
\hline Variables & \multicolumn{3}{|c|}{ Value of M\&As } & \multicolumn{3}{|c|}{ Number of M\&As } \\
\hline BothinSADC & $\begin{array}{l}-3.115^{*} \\
(1.757)\end{array}$ & & $-4.152 * *$ & $\begin{array}{l}2.249 * \\
(1.269)\end{array}$ & $\begin{array}{c}2.729 \\
(1.741)\end{array}$ & $\begin{array}{c}2.595 \\
(1.763)\end{array}$ \\
\hline OneinSADC & $-4.467 * * *$ & $\begin{array}{l}-1.350^{*} \\
(0.797)\end{array}$ & $\begin{array}{c}-5.496^{* * *} \\
(1.900)\end{array}$ & $\begin{array}{c}1.491 \\
(1.182)\end{array}$ & $\begin{array}{c}1.971 \\
(1.690)\end{array}$ & $\begin{array}{c}1.840 \\
(1.711)\end{array}$ \\
\hline Corruption Acquiror & $\begin{array}{c}0.823^{* *} \\
(0.348)\end{array}$ & & & $\begin{array}{c}0.154 \\
(0.100)\end{array}$ & & \\
\hline $\begin{array}{l}\text { Corruption } \\
\text { Target }\end{array}$ & $\begin{array}{c}0.486^{* * *} \\
(0.218)\end{array}$ & & & $\begin{array}{c}0.249^{* * *} \\
(0.078)\end{array}$ & & \\
\hline $\begin{array}{l}\text { Rule of Law } \\
\text { Acquiror }\end{array}$ & & $\begin{array}{c}0.081 \\
(0.349)\end{array}$ & & & $\begin{array}{c}0.255 \\
(0.192)\end{array}$ & \\
\hline $\begin{array}{l}\text { Rule of Law } \\
\text { Target }\end{array}$ & & $\begin{array}{l}-0.389 \\
(0.419)\end{array}$ & & & $\begin{array}{r}0.23 \\
(0.1\end{array}$ & \\
\hline $\begin{array}{l}\text { Political Stability } \\
\text { Acquiror }\end{array}$ & & & $\begin{array}{l}0.359^{* *} \\
(0.177)\end{array}$ & & & $\begin{array}{c}0.198 * * * \\
(0.057)\end{array}$ \\
\hline $\begin{array}{l}\text { Political Stability } \\
\text { Target }\end{array}$ & & & $0.455^{* *}$ & & & $0.190 * * *$ \\
\hline Bilateral Trade & $0.259 * * *$ & $\begin{array}{c}0.263 * * * \\
(0.051)\end{array}$ & $\begin{array}{c}0.261 * * * \\
(0.052)\end{array}$ & $\begin{array}{c}0.282 * * * \\
(0.047)\end{array}$ & $\begin{array}{l}0.283 * * * \\
(0.047)\end{array}$ & $\begin{array}{c}0.282 * * * \\
(0.047)\end{array}$ \\
\hline Exchange Rate & $\begin{array}{l}-0.188 \\
(0.274)\end{array}$ & $\begin{array}{l}-0.323 \\
(0.341)\end{array}$ & $\begin{array}{l}-0.299 \\
(0.331)\end{array}$ & $\begin{array}{r}0.064 \\
(0.149)\end{array}$ & $\begin{array}{c}0.067 \\
(0.154)\end{array}$ & $\begin{array}{c}0.077 \\
(0.154)\end{array}$ \\
\hline Log Distance & $\begin{array}{r}-0.406 \\
(0.08\end{array}$ & $\begin{array}{r}-0.40 \\
-(0.0\end{array}$ & $-0.404 * * *$ & $-0.565 * * *$ & $\begin{array}{r}-0.56 \\
(0.0\end{array}$ & $\begin{array}{c}-0.565 * * * \\
(0.068)\end{array}$ \\
\hline Log GDP Acquiror & $\begin{array}{c}1.970^{* * *} \\
(0.500)\end{array}$ & $2.177 * * *$ & $2.165 * * *$ & $2.495 * * *$ & $2.531 * * *$ & $2.599 * * *$ \\
\hline Log GDP Target & $1.742^{* * *}$ & $1.983 * * *$ & $1.799 * * *$ & $0.849 * * *$ & $0.893 * * *$ & $\begin{array}{c}0.920 * * * \\
(0.185)\end{array}$ \\
\hline Common Language & $\begin{array}{c}0.214 \\
(0.140)\end{array}$ & $\begin{array}{c}0.211^{*} \\
(0.140)\end{array}$ & $\begin{array}{l}0.213^{*} \\
(0.140)\end{array}$ & $\begin{array}{c}0.649 * * * \\
(0.095)\end{array}$ & $0.648^{* * *}$ & $\begin{array}{c}0.649 * * * \\
(0.095)\end{array}$ \\
\hline Common Colony & $\begin{array}{l}0.515^{* *} \\
(0.272)\end{array}$ & $\begin{array}{l}0.524^{*} \\
(0.272)\end{array}$ & $0.524 *$ & $\begin{array}{c}0.570 * * * \\
(0.272)\end{array}$ & $0.573 * * *$ & $\begin{array}{c}0.572^{* * *} \\
(0.239)\end{array}$ \\
\hline Former Col & $\begin{array}{c}0.377^{* * *} \\
(0.128) \\
\end{array}$ & $\begin{array}{c}0.386^{* * *} \\
(0.126)\end{array}$ & $\begin{array}{c}0.388^{* * *} \\
(0.126) \\
\end{array}$ & $\begin{array}{c}0.535^{* * *} \\
(0.086) \\
\end{array}$ & $\begin{array}{c}0.537 * * * \\
(0.085)\end{array}$ & $\begin{array}{c}0.538^{* * *} \\
(0.085) \\
\end{array}$ \\
\hline
\end{tabular}

(Notes) Gravity model of bilateral cross-border M\&A in Africa using PPML. Country dummies for both acquiror and target countries and year dummies are included in all regressions but are not reported. 
Observations clustered within country pairs. *** means significant at $1 \%$, ** means significant at $5 \%$ and * means significant at $10 \%$. Standard errors are in brackets. The number of observations for the value of M\&A is 156,927 and for the number of M\&A is 174,450 . Pseudo $R^{2}$ for the value of M\&A is 0.39 and for the number of M\&A is 0.76

The findings for ECOWAS show interesting differences with respect to the number of M\&A deals in Table 3. BothinECOWAS produces a positive and significant result with a high coefficient. The results imply that when both countries are members of ECOWAS (BothinECOWAS), the number of M\&A deals would increase by approximately six, whereas if only one country is a member of ECOWAS (OneinECOWAS) the number of M\&A would increase by approximately three. The relatively large positive impact from ECOWAS could be attributed to an increase in cross-border private investment in the ECOWAS region, especially in the banking, oil and entertainment sectors (Ogbonna et al. 2013). For instance, Nigerian banks have expanded into ECOWAS countries, which is expected to further encourage intra-regional trade and investment (Dada and Adeleke 2015).

Regarding the effect of SADC on intra-regional M\&As, Table 4 shows that BothinSADC has a negative and significant coefficient for the value of M\&A flows suggesting that SADC discourages M\&A flows within the regional economic bloc. This result is unexpected, given the significant influence, in terms of both trade and investment, of South Africa and Mauritius within the region, and initiatives such as the Southern Africa Regional Power Pool. Perhaps these provisions and initiatives are targeting the greenfield mode of entry for FDI. Perhaps the benefit of FDI from the regional grouping could be going to a few member countries, and not benefiting the overall region. Bouët et al. (2017) commented that the actual level of trade among African countries is below average, as defined by their level of GDP and the distance between countries.

The result for OneinSADC, which indicates the effect of SADC on extra-regional M\&As, is also not encouraging. We observe that even though the SADC investment protocol has specifically provided for extra-regional FDI, this provision does not have any significant positive influence on M\&A flows to the region. In other words, the investment provision discourages FDI in the form of M\&As from the SADC region.

\section{The effect of monetary union on cross-border M\&A in Africa.}

The result for WAEMU in Table 2 using the number of M\&A deals as the dependent variable is similar to the result obtained for the ECOWAS region. We note that the eight mainly French-speaking members of WAEMU are also included in the ECOWAS economic bloc. Using the value of M\&A deals, Table 2 shows BothinWAEMU and OneinWAEMU have a negative insignificant effect. However, when we consider the number of M\&A deals we find that BothinWAEMU has a positive significant effect while OneinWAEMU's effect is positive but insignificant. 


\section{Conclusion}

This paper examined the effect of regional integration on cross-border M\&A flows in Africa for the period 2000 to 2014 . We introduced a measure of economic proximity, such as participation in regional integration, into a structural gravity model developed by Head and Ries (2008). We compiled a global dataset for gross bilateral flows of completed M\&A transactions obtained from the Zephyr database and used the PPML to analyze the data. We investigated the effect of six regional economic blocs in Africa that are at different levels of integration. We found that the SACU and the EAC customs unions promoted M\&A flows between member countries, but not M\&A originating from non-member countries, perhaps the result of the relatively small size of the economic blocs. However, the COMESA and the SADC did not seem to encourage either intra- or extra-regional M\&A, in spite of explicit investment provisions for regional investment. Results for the WAEMU and ECOWAS indicate a significant positive influence of economic integration agreements on the number of cross-border M\&A deals, but not the value of cross-border M\&A flows.

Received 16 October 2018, Revised 30 January 2019, Accepted 31 January 2019 


\section{References}

Agbloyor, E. K., Abor, J., Adjasi, C. K., \& Yawson, A. Domestic banking sector development and cross border mergers and acquisitions in Africa. Review of Development Finance, 2 (1) (2012): $32-42$.

Ahern, K. R., Daminelli, D., \& Fracassi, C. Lost in translation? The effect of cultural values on mergers around the world. Journal of Financial Economics, 117 (1) (2015): 165-189.

Alfaro, L., Kalemli-Ozcan, S., \& Volosovych, V. Capital flows in a globalized world: The role of policies and institutions. In Capital Controls and Capital Flows in Emerging Economies: Policies, Practices and Consequences. University of Chicago Press, 19-72, 2007.

Allard, C, Kriljenko, J., Chen, W, Gonzalez-Garcia, J, Kitsios, E, \& Trevino, J. Trade integration and global value chains in Sub-Saharan Africa. African Department, International Monetary Fund Washington, DC, (2016).

Anderson, J. E. \& Van Wincoop, E. Gravity with gravitas: a solution to the border puzzle. The American Economic Review, 93 (1) (2003): 170-192.

Anderson, S. P., De Palma, A., \& Thisse, J. F. Discrete choice theory of product differentiation. MIT press, Cambridge MA, 1992.

Barrell, R. \& Velde, D. Willem te. European integration and manufactures import demand: an empirical investigation of ten European countries. German Economic Review, 3 (3) (2002): 263-293.

Blomstrom, M. \& Kokko, A. Regional integration and Foreign Direct Investment. Tech. rep. National Bureau of Economic Research, Cambridge MA, (1997).

Brainard, S. L. A simple theory of multinational corporations and trade with a trade-off between proximity and concentration. Tech. rep. National Bureau of Economic Research, (1993).

Brakman, S., Garretsen, H., \& Van Marrewijk, C. Cross-border mergers and acquisitions: on revealed comparative advantage and merger waves. Tinberg Institute Discussion Paper, 08-013 (2), (2007).

Brenton, P., Di Mauro, F., \& Lücke, M. Economic integration and FDI: An empirical analysis of foreign investment in the EU and in Central and Eastern Europe. Empirica, 26 (2) (1999): 95-121. 
Bouët, A., Cosnard, L. and Laborde, D. Measuring trade integration in Africa. Journal of Economic Integration, (2017): 937-977.

Coeurdacier, N., De Santis, R. A., \& Aviat, A. Cross-border mergers and acquisitions and European integration. Economic Policy, 24 (57) (2009): 56-106.

Dada, E. \& Adeleke, A. An empirical analysis of integration and intra-regional trade in ECOWAS. Journal of African Development, 17 (1) (2015): 95-116.

Dai, M., Yotov, VY., and Zylkin, T. On the trade-diversion effects of free trade agreements. Economics Letters, 122 (2014): 321-325

Di Giovanni, J. What drives capital flows? The case of cross-border M\&A activity and financial deepening. Journal of International Economics, 65 (1) (2005): 127-149.

Dunning, J. H. Location and the multinational enterprise: John Dunning's thoughts on receiving the" Journal of International Business Studies" 2008 Decade Award. Journal of International Business Studies, (2009): 20-34.

Erel, I., Liao, R. C., \& Weisbach, M. S. Determinants of cross-border mergers and acquisitions. The Journal of Finance, 67 (3) (2012): 1045-1082.

Frankel, J. A. \& Rose, A. K. The endogenity of the optimum currency area criteria. The Economic Journal, 108 (449) (1998): 1009-1025.

Froot, K and J. Stein "Exchange Rates and Foreign Direct Investment: An Imperfect Capital Markets Approach” Quarterly Journal Economics, 106(4), (1991): 1191-1217

Fudenberg, D. \& Tirole, J. Game theory. Cambridge, MA, 393, (1991).

Head, K. \& Ries, J. FDI as an outcome of the market for corporate control: Theory and evidence. Journal of International Economics, 74 (1) (2008): 2-20.

Hyun, H.-J. \& Kim, H. H. The determinants of cross-border M\&As: The role of institutions and financial development in the gravity model. The World Economy, 33 (2) (2010): 292-310.

Jongwanich, J., Brooks, D. H., \& Kohpaiboon, A. Cross-border mergers and acquisitions and financial development: Evidence from emerging Asia. Asian Economic Journal, 27 (3) (2013): 265-284.

Kamaly, A. Trends and determinants of mergers and acquisitions in developing countries in the 1990s. International Research Journal of Finance and Economics, 8 (2007): 16-30. 
Levy-Yeyati, E. L., Stein, E., \& Daude, C. Regional integration and the location of FDI. InterAmerican Development Bank Research Department Washington DC Working Paper No. 492, (2003).

Neary, J. P. Cross-border mergers as instruments of comparative advantage. The Review of Economic Studies, 74 (4) (2007): 1229-1257.

Neary, J. P. Trade costs and Foreign Direct Investment. International Review of Economics \& Finance, 18 (2) (2009): 207-218.

Neto, P., Brandão, A., \& Cerqueira, A. The macroeconomic determinants of cross-border mergers and acquisitions and greenfield investments. IUP Journal of Business Strategy, 7 (1/2) (2010): 21 .

Netter, J., Stegemoller, M., \& Wintoki, M. B. Implications of data screens on merger and acquisition analysis: A large sample study of mergers and acquisitions from 1992 to 2009. Review of Financial Studies, 24 (7) (2011): 2316-2357.

Njoroge, L. \& Ouma, S. Determinants of bank expansion in the East African Community: An empirical analysis of Kenyan banks. Kenya Bankers Association Centre for Research on Financial Markets and Policy Working Paper Series, (9) (2014).

Nocke, V. \& Yeaple, S. Cross-border mergers and acquisitions vs. greenfield Foreign Direct Investment: The role of firm heterogeneity. Journal of International Economics, 72 (2) (2007): $336-365$.

Ogbonna, C., Aluko, B., \& Awuah, K. The ECOWAS platform and the persisting challenges of integrating the West African Region: A discourse. Journal of Economics and Sustainable Development, 4 (1) (2013).

Pozzolo, A. F. Bank cross-border mergers and acquisitions: causes, consequences, and recent trends. The Changing Geography of Banking and Finance. Springer, (2009): 155-183.

Rossi, S. \& Volpin, P. F. Cross-country determinants of mergers and acquisitions. Journal of Financial Economics, 74 (2) (2004): 277-304.

Sachs, J., McArthur, J., Schmidt-Traub, G, Kruk, M, Bahadur, C, Faye, M, \& McCord, G. Ending Africa's Poverty Trap. New York: United Nations, (2004).

Silva, J. S. \& Tenreyro, S. The log of gravity. The Review of Economics and Statistics, 88 (4) (2006): 641-658. 
Silva, J. S. \& Tenreyro, S. Comments on "The log of gravity revisited." Manuscript, London School of Economics, (2009).

Silva, J. S. \& Tenreyro, S. Currency unions in prospect and retrospect. Annual Review of Economics, 2 (1) (2010): 51-74.

Silva, J. S. \& Tenreyro, S. On the existence of the maximum likelihood estimates in Poisson regression. Economics Letters, 107 (2) (2010a): 310-312.

Te Velde, D. W. \& Bezemer, D. Regional integration and Foreign Direct Investment in developing countries. Transnational Corporations, 15 (2) (2006): 41-70.

Tunyi, A. A. \& Ntim, C. G. Location advantages, governance quality, stock market development and firm characteristics as antecedents of African M\&As. Journal of International Management, 22 (2) (2016): 147-167.

UNCTAD. World Investment Report 2006: FDI from developing and transition economies: implications for development. United Nations, New York \& Geneva, (2006).

UNCTAD. World Investment Report 2014: Investing in the SDGs: An action Plan. United Nations, New York \& Geneva, (2014).

Warin, T.,Wunnava, P. V., \& Janicki, H. P. Testing Mundell's intuition of endogenous OCA theory. Review of International Economics, 17 (1) (2009): 74-86.

Wilson, M. K. \& Vencatachellum, D. J. M. Determinants of cross-border mergers and acquisitions targeting Africa: 1991-2011. Tech. rep. Economic Research Southern Africa, (2016). 